\title{
Crp And Uric Acid Levels As Aprognostic Markers In Acute Myocardial Infrction
}

\author{
Dr. Srikanth ,Md
}

\begin{abstract}
Introduction: Cardiovascular disease is responsible for $30 \%$ of all deaths in the world. About $80 \%$ of the global burden of CVD death occurs in low and middle income countries. India carries a significant portion of this CVD burden. Acute myocardial infarction continues to be the major public health problem in the industrialized and developing countries like India despite progressive research in diagnosis and management over last three decades.

Until now, various bio-markers have been studied in patients of acute coronary syndrome. However, no single marker gives definite prognostic information during the course of the disease. Little information is available about the role of different individual bio markers. Hence a study is attempted using two easily measured, broadly available biomarkers namely serum Uric Acid, and C-reactive protein targeting different risk indicators like purine metabolism, and inflammation as a tool for assessment in Acutemyocardial infarction.

objectives

1)To assess serum c-reactive protein and serum uric acid levels determined on admission as a potential predictor in acute myocardial infarction (AMI) patients.

2)To see for correlation with CRP and hyperuricaemia with Killip's class and mortality.

Source of data:

Source of data: All cases admitted to ICCU in Basaveshwara Teaching and GeneralHospital attached to M.R. Medical College, Kalaburagi with acute myocardial infarction.

Study design: It is a prospective case control study from BTGH during study period fromDec 2014 to May 2016. A minimum of 100 cases which were diagnosed as acutemyocardial infarction and 100 controls who were healthy volunteers taken.
\end{abstract}

Materials\& methods: All cases and controls were taken from BTGH Gulbarga by applyinginclusion andExclusion criteria

Results

1. A total of 100 patients were who presented with acute myocardial infarction and 100 controls who are healthy people who came to Basaveshwara teaching and general hospital studied.

2. $75 \%$ were males and $25 \%$ were females. The male to female ratio was 3:1.

3. Majority were in the age group of 51-70 years (59\%) both in cases and controls $27 \%$ belonged to $31-50$ years, followed by $14 \%$ in 61-85 years. Mean age was58.5 years. In control group it is 57.1 years.

4. Most common presenting complaint is chest pain $66 \%$, followed by $32 \%$ patients presented with both chest pain and dyspnea.

5. Out of 100 patients, 54\% patients were overweight, 9\% belonged to obesity class I, 3\% to obesity class II and $34 \%$ of study population had normal BMI.

6. Dyslipidemia was the major risk factor (79\%) followed by hypertension (62\%).

7. Out of the 100 patients with AMI $61 \%$ had STEMI, $39 \%$ patients had NSTEMI and AWMI is the most common STEMI seen in $50.8 \%$.

8. Out of 100 patients $59 \%$ patient developed cardiogenic shock, $13.6 \%$ developed complete heart block, $18.1 \%$ had ventricular tachycardia and 9\% developed ventricular fibrillation. 22 (22\%) patients succumbed.

9. Serum uric acid and CRP is significantly elevated in patients with acutemyocardial infarction when compared with controls.

10. Serum uric Acid (>7.5mg \%) and CRP> $2.0 \mathrm{mg} / \mathrm{dl}$ is associated with highmortality irrespective of day of admission.

\section{Introduction}

Acute myocardial infarction (AMI) continues to be a major public health problem in the in industrialized and developing countries like India despite progressive research in diagnosis and management over the last three decades1. It is due to death of heart muscle from the sudden blockage of a coronary artery by a blood clot (or) coronary thrombosis. 
Inflammation plays a key role in the initiation and promotion of atherosclerotic lesions and can trigger myocardial infarction by the induction of plaque instability.CRP is a extensively studied inflammatory marker whose prognostic value in cardiovascular disease in recent years has become increasingly important. Recent evidence suggest that uric acid may be an important causal agent in cardiovascular disease, both animal and human studies have recently shown that the high uric acid levels may impair kidney function by causing glomerular damage and pre-glomerular arteriosclerosis that ultimately result in arterial hypertension4. Uric acid is an important risk factor for cardio vascular mortality. Xanthine oxidase ${ }^{5}$ and uric acid synthesis ${ }^{6}$ are increased in vivo under ischaemic condition, and therefore elevated serum uric acid may act as a marker of underlying ischaemia. Hence, the present study is an attempt to understand the behavior and response of uric acid, CRP in AMI patients. Hence monitoring of these parameters would be beneficial following AMI and is highly recommended to improve patients outcome.

\section{Materials \& methods}

All cases and controls were taken from BTGH Gulbarga by applyinginclusion andExclusion criteria.

\section{Inclusion criteria}

Patients with diagnosis of AMI based on WHO definition with any two of criteria namely

1. Typical ischaemic chest pain,

2. Raised cardiac enzymes,

3. Typical electrocardiography (ECG) findings including development of pathological Q waves were included.

\section{Exclusion criteria}

1. Patients with non-cardiac chest pain,

2. Acute infectious disease known (or) suspected neoplastic diseases,

3. Recent (less than 3 months) Major trauma (or) surgery, burns

4. Immune suppressive drug therapy, immunological disorders, osteoarthritis,

Rheumatoid arthritis, gout, ankylosing spondylitis, psoriatic arthritis were excluded from study. All patients underwent clinical examination and detailed history laboratory investigations such as routine blood investigations, Serum CRP, serum uric acid samples will be collected on day $0,3,5$ from the onset of symptoms ECG and echocardiography will be taken. Patients were followed up for 7 days in the hospital and observed to complication Such as LVF, cardiogenicshock, arrhythmias

\section{Results}

Hundred patients presenting with acute myocardial infarction who satisfied the inclusion criteria were enrolled into the study. Data was collected and analyzed with clinical and laboratory parameters. Results are as follows.

Table-Age in years

\begin{tabular}{|l|l|l|l|l|}
\hline \multirow{2}{*}{ Age in years } & \multicolumn{2}{|l|}{ Cases $(\mathbf{n = 1 0 0})$} & \multicolumn{2}{l|}{ Controls $(\mathbf{n}=100)$} \\
\cline { 2 - 5 } & Males & Females & Males & Females \\
\hline $31-50$ years & 23 & 4 & 16 & 8 \\
\hline $51-70$ years & 43 & 16 & 53 & 15 \\
\hline $71-85$ years & 9 & 5 & 6 & 2 \\
\hline Total & 75 & 25 & 75 & 25 \\
\hline Mean \pm SD & $58.5 \pm 12$ & & $57.10+10$ & \\
\hline
\end{tabular}

Fischer exact test $\mathrm{p}=1.00 \mathrm{NS}$

Out of 100 patients total 75 were males and 25 were females .most of the patients age was in between 51-70 years(59 patients),followed by 31-50 (27 patients). Least in between 71-85(14).controls also were in the same fashion.Out of the 100 patients in the cases $27 \%$ patients are between age group of $31-50$ years , 58\% between $51-70$ years \& $15 \%$ between $71-85$ years in case group and in control group $26 \%, 66 \%, 8 \%$ between 31 50 years, 5 1-70 years, \& 71-85 years respectively. 
Table : Serum Uric acid and Killip's Classification on day 0 in cases

\begin{tabular}{|l|l|l|l|l|}
\hline \multicolumn{2}{|c|}{} & \multicolumn{2}{|l|}{ Serum Uric Acid value } & \multirow{2}{*}{ Total } \\
\cline { 3 - 4 } \multicolumn{2}{|c|}{ Killip's Class } & Abnormal & Normal & \\
\cline { 2 - 4 } & II & $23(56 \%)$ & $18(43.9 \%)$ & 41 \\
\cline { 2 - 4 } & III & $25(65.7 \%)$ & $13(34.2 \%)$ & 38 \\
\cline { 2 - 4 } & IV & $5(83.3 \%)$ & $1(16.6 \%)$ & 6 \\
\hline \multicolumn{2}{|l|}{ Total } & $10(66.6 \%)$ & $5(33.3 \%)$ & 15 \\
\hline
\end{tabular}

Fishers exact test $\mathbf{p}=\mathbf{0 . 5}$, Significant

Out of 6 patients belongs to killip's class III 5(83.3\%) patients had elevated serum uric acid levels, $1(16.6 \%)$ had normal serum uric acid level. Out of 15 patients killip's class IV, $10(66.6 \%)$ patients had elevated serum uric acid Ievels,,5(33.3\%) patients had normal serum uric acid levels, this result was statistically significant with $\mathrm{p}$ value 0.5 .

Table : Serum Uric acid and Killip's Classification on day 3

\begin{tabular}{|l|l|l|l|l|}
\hline \multicolumn{2}{|c|}{} & \multicolumn{2}{|c|}{ Serum Uric Acid value } & \multirow{2}{*}{ Total } \\
\cline { 3 - 5 } Killip's Class & I & $22(53.6 \%)$ & $19(46.4 \%)$ & 41 \\
\cline { 2 - 5 } & II & $23(60.5 \%)$ & $15(39.5 \%)$ & 38 \\
\cline { 2 - 5 } & III & $4(66.6 \%)$ & $2(33.3 \%)$ & 6 \\
\cline { 2 - 5 } & IV & $10(66.6 \%)$ & $5(33.3 \%)$ & 15 \\
\hline Total & $\mathbf{5 9}(\mathbf{5 9 \%})$ & $\mathbf{4 1}(\mathbf{4 1 \%})$ & $\mathbf{1 0 0}$ \\
\hline
\end{tabular}

Fishers exact test $\mathbf{p}=\mathbf{0 . 5}$, Significant

Out of 41 killip's class I patients $22(53.6 \%)$,out of 38 killip's class II $23(60.5 \%)$ Out of 6killips class III $4(66.6 \%)$, and $10(66.6 \%)$ out of 15 killip's class IV had elevated serum uric acid levels. this is statistically significant with $\mathrm{p}$ value being 0.5 .

Table : Serum Uric acid and Killip's Classification on day 5

\begin{tabular}{|l|l|l|l|l|}
\hline \multicolumn{2}{|c|}{} & \multicolumn{2}{|l|}{ Serum Uric Acid value } & \multirow{2}{*}{ Total } \\
\cline { 3 - 5 } \multicolumn{2}{|c|}{} & Abnormal & Normal & \\
\hline \multirow{5}{*}{ Killip's Class } & I & $22(53.6 \%)$ & $19(46.4 \%)$ & 41 \\
\cline { 2 - 5 } & II & $25(65.7 \%)$ & $13(34.2 \%)$ & 38 \\
\cline { 2 - 5 } & III & $6(100 \%)$ & $0(0 \%)$ & 6 \\
\cline { 2 - 4 } & IV & $14(93.3 .6 \%)$ & $1(6.66 \%)$ & 15 \\
\hline \multicolumn{2}{|l|}{ Total } & $\mathbf{6 7}(\mathbf{6 7 \%})$ & $\mathbf{3 3 ( 3 3 \% )}$ & $\mathbf{1 0 0}$ \\
\hline
\end{tabular}

Fishers exact test $\mathrm{p}$ 0.5, Significant.

Out of41 killip's class I patients, 22(53.6\%) patients, 25(65.4\%)patients out of 38 killip's class II, $6(100 \%)$ out of 6 killip's class III, $10(66.6 \%)$ out of 15 patients belongs to killip's classification had elevated serum uric acid levels. This is statistically significant with $\mathrm{p}$ value is being 0.5 .

Table : CRP and killip's classification on day 0

\begin{tabular}{|l|l|l|l|l|}
\hline \multicolumn{2}{|c|}{} & C reactive protein value & \multirow{2}{*}{ Total } \\
\cline { 3 - 5 } \multicolumn{2}{c|}{ Killip's Class } & Abnormal & Normal & \\
\cline { 2 - 5 } & I & $23(56.09 \%)$ & $18(43.9 \%)$ & 41 \\
\cline { 2 - 5 } & II & $24(63.1 \%)$ & $14(58.3 \%)$ & 38 \\
\cline { 2 - 4 } & III & $5(83.3 \%)$ & $1(16.6 \%)$ & 6 \\
\cline { 2 - 4 } TV & $13(86.6 \%)$ & $2(13.3 \%)$ & 15 \\
\hline
\end{tabular}

Fishers exact test p 0.5 Significant

Out of 15 killip's class IV patients, $13(86.6 \%)$ patients ,5 (83.3\%) patients of killip's class III of them had elevated C-reactive protein levels this is statistically significant.

Table : CRP and killip's classification on day 3

\begin{tabular}{|l|l|l|l|l|}
\hline \multicolumn{2}{|c}{} & \multicolumn{2}{|c|}{ C reactive protein value } & \multirow{2}{*}{ Total } \\
\cline { 2 - 5 } \multicolumn{2}{c|}{ Killip's Class } & Abnormal & Normal & \\
\cline { 2 - 5 } & II & $22(53.6 \%)$ & $19(46.3 \%)$ & 41 \\
\cline { 2 - 5 } & III & $20(52.6 \%)$ & $18(47.3 \%)$ & 38 \\
\cline { 2 - 5 } & IV & $15(83.3 \%)$ & $1(16.6 \%)$ & 6 \\
\hline Total & $\mathbf{6 5}(\mathbf{1 5 \%})$ & $0(33.3 \%)$ & 15 \\
\hline
\end{tabular}




\section{Fishers exact test p 0.5 Significant}

Out of4l patients $22(53.6 \%)$ patient in killip's class I, $20(52.6 \%)$ out of 38 patients of killip's class II, $5(83.3 \%)$ out of 6 patients of killip's class III, and 15(100\%) of killip's classIV had raised serum uric acid level. This is statistically significant.

Table : CRP and killip's classification on day 5

\begin{tabular}{|l|l|l|l|l|}
\hline \multicolumn{2}{|c|}{} & \multicolumn{2}{|c|}{ C reactive protein value } & \multirow{2}{*}{ Total } \\
\cline { 3 - 5 } \multicolumn{2}{c|}{ Abnormal } & Normal & \\
\hline \multirow{3}{*}{ Killip's Class } & I & $19(46.3 \%)$ & $22(53.6 \%)$ & 41 \\
\cline { 2 - 5 } & II & $14(36.4 \%)$ & $24(63.1 \%)$ & 38 \\
\cline { 2 - 5 } & III & $4(66.6 \%)$ & $2(33.3 \%)$ & 6 \\
\cline { 2 - 5 } & IV & $14(93.3 \%)$ & $1(6.7 \%)$ & 15 \\
\hline \multicolumn{2}{|l|}{ Total } & $\mathbf{2 3 ( 2 3 \% )}$ & $\mathbf{7 7}(\mathbf{7 7 \%})$ & $\mathbf{1 0 0}$ \\
\hline
\end{tabular}

Fishers exact test $\mathrm{p}=0.5$ Significant

Out of 41 patients of killip's class 1, 19(46.3\%), out of 38 killip's class II patients14(36.4\%) patients, $4(66.6 \%)$ out of 6 killip's class III, and 14(93.3\%) out of 15 killip's class IV had elevated levels of C-reactive protein, this value is statistically significant.

Table 12: CRP and killip's classification on day 5

\begin{tabular}{|l|l|l|l|l|}
\hline \multicolumn{2}{|c|}{} & \multicolumn{2}{|c|}{ C reactive protein value } & \multirow{2}{*}{ Total } \\
\cline { 3 - 5 } Killip's Class & I & $19(46.3 \%)$ & $22(53.6 \%)$ & 41 \\
\cline { 2 - 5 } & II & $14(36.4 \%)$ & $24(63.1 \%)$ & 38 \\
\cline { 2 - 5 } & III & $4(66.6 \%)$ & $2(33.3 \%)$ & 6 \\
\cline { 2 - 4 } & IV & $14(93.3 \%)$ & $1(6.7 \%)$ & 15 \\
\hline Total & $\mathbf{2 3}(\mathbf{2 3 \%})$ & $\mathbf{7 7}(\mathbf{7 7 \%})$ & $\mathbf{1 0 0}$ \\
\hline
\end{tabular}

Fishers exact test $\mathrm{p}=0.5$ Significant

Out of 41 patients of killip's class 1, 19(46.3\%), out of 38 killip's class II patients14(36.4\%) patients, $4(66.6 \%)$ out of 6 killip's class III, and 14(93.3\%) out of 15 killip's class IV had elevated levels of C-reactive protein, this value is statistically significant

Table : Serum Uric acid and Mortality

\begin{tabular}{|l|l|l|l|l|}
\hline \multicolumn{2}{|c|}{} & \multicolumn{2}{|l|}{ Serum uric acid value } & \multirow{2}{*}{ Total } \\
\cline { 3 - 4 } \multicolumn{2}{|c|}{} & Abnormal & Normal & \\
\hline \multirow{2}{*}{ Death } & Yes & $16(72.7 \%)$ & $6(27.2 \%)$ & 22 \\
\cline { 2 - 4 } & No & $36(46.1 \%)$ & $42(53.8 \%)$ & 78 \\
\hline \multicolumn{2}{|l|}{ Total } & $\mathbf{5 2}(\mathbf{5 2 \%})$ & $\mathbf{4 8}(\mathbf{4 8 \%})$ & $\mathbf{1 0 0}$ \\
\hline
\end{tabular}

Fishers exact test $\mathrm{p}$ 0.03, Significant.

Among 22 patients who died $16(72.7 \%)$ had elevated serum uric acid levels. The results were statistically significant. The patients with serum uric acid level $>7.5 \mathrm{mg} / \mathrm{dl}$ on day 0,7 out of 9 patients were died by day 3 . All patients with serum uric acid levels $>6.0 \mathrm{mg} / \mathrm{dl}$ on day 0 , expired by day 5 .

Table : C reactive protein and Mortality

\begin{tabular}{|l|l|l|l|l|}
\hline \multicolumn{2}{|c|}{} & \multicolumn{2}{|l|}{ C reactive protein value } & \multirow{2}{*}{ Total } \\
\cline { 3 - 4 } \multicolumn{2}{c|}{ Abnormal } & Normal & \\
\hline \multirow{2}{*}{ Death } & Yes & $21(95.4 \%)$ & $1(4.5 \%)$ & 22 \\
\cline { 2 - 5 } & No & $44(56.4 \%)$ & $34(43.5 \%)$ & 78 \\
\hline \multicolumn{2}{|l|}{ Total } & $\mathbf{6 5}(65 \%)$ & $\mathbf{3 5}(\mathbf{3 5 \%} \%)$ & $\mathbf{1 0 0}$ \\
\hline
\end{tabular}

Fishers exact test $\mathrm{p}=0.0004$, extremely significant.

21 patients $(95.4 \%)$ all deaths had elevated $\mathrm{C}$ reactive protein levels, and 1 deaths had normal $\mathrm{C}$ reactive protein. The results were statistically significant.

The patients with CRP values $>2.0 \mathrm{mg} / \mathrm{dl}$ on day of admission, 6 out of 7 had mortality by day 3. Out of 22 with mortality in case group, all cases with CRP values between $1-2 \mathrm{mg} / \mathrm{dl}$ had mortality by day 5

Table: Relation between uric acid level and Killip's class and death

\begin{tabular}{|c|c|c|c|c|c|c|c|c|c|}
\hline \multirow{3}{*}{$\begin{array}{l}\text { Killip's } \\
\text { Class }\end{array}$} & \multicolumn{3}{|c|}{ Uric acid Day 0} & \multicolumn{3}{|c|}{ Uric acid day 3} & \multicolumn{3}{|c|}{ Uric acid day 3} \\
\hline & $<5.5$ & $5.6-7.5$ & $>7.6$ & $<5.5$ & $5.6-7.5$ & $>7.6$ & $<5.5$ & $\begin{array}{l}5.6- \\
7.5\end{array}$ & $>7.6$ \\
\hline & \multicolumn{3}{|c|}{\begin{tabular}{|l|} 
No of Deaths \\
\end{tabular}} & \multicolumn{3}{|c|}{ No of Deaths } & \multicolumn{3}{|c|}{ No of Deaths } \\
\hline I & 0 & 0 & 0 & 0 & 0 & 0 & 0 & 0 & 1 \\
\hline
\end{tabular}




\begin{tabular}{|l|l|l|l|l|l|l|l|l|l|}
\hline II & 0 & 0 & 0 & 0 & 1 & 1 & 0 & 2 & 0 \\
\hline III & 0 & 0 & 0 & 0 & 1 & 0 & 0 & 2 & 0 \\
\hline IV & 0 & 0 & 0 & 0 & 3 & 2 & 0 & 7 & 2 \\
\hline Total & 0 & 0 & 0 & 0 & 5 & 3 & 0 & 11 & 3 \\
\hline
\end{tabular}

There are no deaths on admission day (day o).but deaths occurred on subsequent days. Out of 22 deaths 8 deaths occurred on day 3 and 14 deaths occurred after day 3.among deaths class I -1 death, class 11-4 deaths,classIII-3 deaths and class IV- 14 deaths occurred. Most of the deaths in class IV \& III are associated with higher uric acid level. Serum uric acid level $>7 \mathrm{mg} / \mathrm{dl}$ with killip's class III \& IV are associated with high mortality.

Table : Relation of elevated CRP correlation with killip's class and death

\begin{tabular}{|c|c|c|c|c|c|c|c|c|c|}
\hline \multirow{3}{*}{$\begin{array}{l}\text { Killips } \\
\text { Class }\end{array}$} & \multicolumn{3}{|c|}{ CRP Day 0} & \multicolumn{3}{|c|}{ CRP Day 3} & \multicolumn{3}{|c|}{ CRP Day 5} \\
\hline & $<1$ & $1-3$ & $>3$ & $<1$ & $1-3$ & $>\mathbf{3}$ & $<1$ & 1-3 & $>3$ \\
\hline & \multicolumn{3}{|c|}{ No of Deaths } & \multicolumn{3}{|c|}{ No of Deaths } & \multicolumn{3}{|c|}{ No of Deaths } \\
\hline I & 0 & 0 & 0 & 0 & 0 & 0 & 0 & 1 & 0 \\
\hline II & 0 & 0 & 0 & 0 & 1 & 1 & 0 & 2 & 0 \\
\hline III & 0 & 0 & 0 & 0 & 1 & 0 & 0 & 2 & 0 \\
\hline IV & 0 & 0 & 0 & 0 & 5 & 0 & 0 & 9 & 0 \\
\hline Total & 0 & 0 & 0 & 0 & 7 & 1 & 0 & 14 & 0 \\
\hline
\end{tabular}

All deaths occurred after admission day(day O).out of 22 deaths 8 deaths occurred after day 1 and before day 3.and 14 deaths occurred after day 3. .Killip's class I -I death,classll-2deaths,cIassIII-2 deaths,classlV-9deaths occurred

\section{Discussion}

In our study the mean age of occurrence of ACS was 58.7 years. In Foussas et $\mathrm{al}^{33}$ and Kristin Newby et al ${ }^{34}$ study mean age was in seventh decade. In the Indian subcontinent coronary artery disease occurs a decade earlier than the western population. Mean age of our patients correlates with above mentioned studies

\section{Serum uric Acid as predictor of mortality}

Our study had 22\% ( $\mathrm{n}=22)$ mortality. All the 22 patients had elevated serum uric acid and CRP values on admission. In our study mean uric acid levels in the cases on day 0 was $6.088 \pm 1.596$ and in the controls it was $3.596 \pm 0.593$. Average uric acid levels were higher in the case group as compared to the control group. This difference seen was also statistically extremely significant $(\mathrm{p}<0.0001)$

In study done ShirishAgarwal et $\mathrm{al}^{32}$ by uric acid levels in the cases on day 0 was $7.03 \pm 1.54$ and in the controls was $5.77 \pm 1.15$. According to MY Nadkar et $\mathrm{al}^{31}$ study the mean uric acid levels in case and control group is $5.23 \pm 1.95$ and $3.78 \pm 0.74$ respectively .Our findings correlate with their studies.

In our study the association of deaths in AMI with UA levels and day of death of the patients was studied. This difference seen was statistically very significant. We also found that, admission UA levels above 7.Omg!dl are associated with highest mortality before day $3(\mathrm{p}<0.05)$.Comparing status of UA on day 0,3 and 5 we noticed that UA levels on day 0 were more significantly associated with mortality as compared to those seen on day 3 and 7. Hence UA level on day 0 alone can be used to predict the prognosis of AMI rather than repeating the test on day 3 and day 5 for economic benefit. In our study correlation between levels of uric acid on day 0 , day 3 and 5 along with Killip's class and the mortality of AMI was studied Uric acid levels were grouped in 3 groups of $<5.5,5.5-7.5,>7.6$. So we conclude that serum uric acid levels were higher in patients with AMI with higher Killip's class. Higher mortality was also observed in patients with high UA and higher Killip's class. Therefore combination of Killip's class and UA level after AMI is a predictor of mortality.

According to study by MY NADKAR et $\mathrm{al}^{31}$ here is a statistically significant higher level of serum uric acid concentration in patients of MI on day of admission as compared to controls. On all the days serum uric acid levels are higher in patients who are in higher Killip's class. All the five patients who died after 3 days of hospital stayhave serum uric acid level more than $7.0 \mathrm{mg} / \mathrm{dl}$ and all of them are in Killip's class IV. Our study correlates with them According to a study by Trkulja $\mathrm{V}$ et al ${ }^{39} \mathrm{~A}$ total of 621 patients (age 2790 years, $64.7 \%$ men, 77.5\% AM! with ST elevation, SUA 63-993 $\mu \mathrm{moL} / \mathrm{L}$ ) are included. Higher SUA on admission is independently associated with higher inhospital mortality (RR, 1.016; 95\% confidence interval [CI], 1.001$1.031, \mathrm{P}=0.043$ ) and higher thirty-day mortality (RR, 1.016; 95\% CI, 1.003-1.029, P 0.018). Higher serum uric acid determined on admission is associated with higher inhospital mortality and poorer long- term survival after AMI, Our study correlates with them.

\section{CRP as a predictor for mortality}

Our study had 22\% (n22) mortality. All the 22 patients had elevated CRP values on admission. 
In our study mean CRP in the cases on day 0 was $.70 \pm 0.74$ and in the controls it was $1.16 \pm 0.96$ Average CRP levels were higher in the case group as compared to the control group in all the 3 days when checked. This difference seen was also statistically extremely significant $(\mathrm{p}<0.001)$ In our study the association of deaths in AMI with CRP levels and day of death of the patients was studied. This difference seen was statistically very significant.

In study done by Baruah et $\mathrm{al}^{25} \mathrm{CRP}$ levels in controls and cases were $0.443 \pm 0.19$ and $3.88 \pm 2.81$, the CRP levels in AMI patients were slightly on the higher side when compared to our study, that may be because of the lab variations in the CRP values that can be taken as significant.

When compared to cases and controls in our study, the CRP values are statistically significant.

We also found that, admission CRP levels above $2.0 \mathrm{mg} / \mathrm{dl}$ are associated with highest mortality before day $3(\mathrm{p}<0.05)$.Comparing status of CRP on day 0,3 and 5 we noticed that CRP levels on day 0 were more significantly associated with mortality as compared to those seen on day 3 and 7 . But we noticed an increasing trend in CRP by day 3 when compared to day of admission which can be used to predict the prognosis of AMI.

Study done by Kushner et $\mathrm{al}^{40}$ the change in the serum concentration of acute phaseprotein in 19 participants after mild and extensive AMI, an increase in crp concentration was seen in all patients. The rate of increase in concentration was found to beexponential with a mean hourly constant for entire group of patients of 0.085 , doubling time is $8.2 \mathrm{hrs}$.

Adriano Caixetaet $\mathrm{al}^{41}$ studied the predictive value of baseline $\mathrm{C}$ reactive proteinon30 day mortality in patients with acute coronary syndrome. Patients with CRP levelsin4th quartile had significantly higher mortality rates $(2.3 \%$ vs $0.3 \% \mathrm{p}=0.0004)$.In our study correlation between levels of CRP day 0 , day 3 and 5 along with Killip's class and the mortality of AMI was studied.

CRP were grouped in 3 groups of $<1,1-3,>3$. So we conclude that CRP levels were higher in patients with AMI with higher Killip's class. Higher mortality was also observed in patients with high CRP and higher Killip's class. Therefore combination of Killip's class and CRP level after AMI is a predictor of mortality. 14 deaths occurred after day 3.killips class I -1 death, classII-2 deaths, class III- 2deaths, classlV-9 deaths.

In the study done by Baruahet $\mathrm{al}^{25}$ serum CRP in AMI patient have a significantly higher value as compared to the control subjects ( $\mathrm{p}<0.01$ ) on day 1 , day 3 , day 5 , and at the time of discharge. This study showed that changes in CRP had a distinctive pattern, an acute phase response with persistent increasing trend with a peak CRP around 3rd day after onset of MI followed by a sustained and a gradual fall by 5th day, followed by decline not reaching baseline by 7th-9th day. The result obtained, matches with our result.

\section{Conclusion}

1. Serum uric acid levels and C-reactive protein can be used as aPotential predictor in acute myocardial infarction.

2. Higher CRP and serum uric acid levels with class III \& IV showed increased mortality.

3. CRP $>2.0 \mathrm{mg} / \mathrm{dl}$ and serum uric acid levels $>9.0 \mathrm{mg} / \mathrm{dl}$ associated with highest mortality irrespective of day of admission.

High serum uric acid on day of admission alone can be used in predicting the severity of AMI which makes it a simple tool for knowing the severity of AMI

\section{References}

[1]. Kushner I, Feldmann G. Control of acute phase response demonstration of C-reactive protein synthesis and section by hepatocytes acute inflammation in the rabbit. J Exp Med 1978 : 148: 466-77.

[2]. S. Kaptoge, E. Di Angelantonio, G Howe et al, c-reactive protein concentration and risk of coronary heart disease, stroke, and mortality: an individual participant meta analysis - The Lancet, Vol. 375, No.9709, pp.132-140, 2010.

[3]. I. Swiatkieoicz, M. Koziniski, P, Magielski et al. Usefulness of c-reactive protein as a marker of early post infarct left ventricular systolic dysfunction. "Inflammation Research, vol. 61, No. 7 pp.725-734. 2012.

[4]. R.J Johnson DH. Kang, D. Feig S. Kivilighn, I Kanellis, S. Waltanabe, KR Tuttle, B Rodriqu Z-Iturbe, J. Herrena - Acosta, and M. Mazali. Is there pathogentic role for uric acid in hypertension and cardiovascular and renal disease " "Hypertension 2003. Pp.11831190 .

[5]. P. Castelli, AM Condemi and C. Brambillasca, Imporvement of cardiac function by alloporinol in patients undergoing cardiac surgery. J Cardiovasc Pharmacol 1995; pp.119-25.

[6]. K. Kogure, M Ishizaki and M. Nemoto. Evaluation of serum uric acid changes in different forms of hepatic vascular inflow occlusion in human liver surgeries. "Life Sci" 1999. Pp.305-13.

[7]. MrigankaBaruah et al. A study to serum uric acid and C reactive protein in acute myocardial infarction. Vol. 2 No.1, June 2012. ISSN: 2049-4963

[8]. Nadkar MY, Jam VI. Serum uric acid in acute myocardial infarction. J Assoc Physicians India 2008; 56: 759-62

[9]. Shirish Agawaral, Swati C, Aundkar, A Patange, Sheen un, Rishi garg. Role of serum uric acid in acute myocardial infarction of prognostic marker. International Journal ofHealth Science and Research.ISSN : 2249-9571

[10]. Foussas SG, Zairis MN, Lyras AG, Patsourakos NG, Tsirimpis VG, Katsaros K et al. Early Prognostic usefulness of C reactive protein added to thrombolysis inmyocardial infarction risk score in acute coronary syndromes. Am J Cardiol 2005; 96:533-7.

[11]. Newby LK, Christenson RH, Ohman EM, Armstrong PW, Thompson TD, Lee KL, et al. Value of serial troponin I measures for early and late risk stratification in patients with acute coronary syndromes. The GUSTO-ha Investigators. Circulation. 1998; 98 $1853-9$ 
[12]. Trkulja V, Car S. On-admission serum uric acid predicts outcomes after acute myocardial infarction: systematic review and metaanalysis of prognostic studies. CroatMedJ 2012; 53: 162-72.

[13]. Irving Kushner et a! study of c reactive kinetics after acute myovardial infarction. The journal of clinical investigation volume 61 February 1978 235-342.

[14]. Caixeta A, Stone GW, Mehran R, Lee EA, McLaurin BT, Cox DA, et al. Predictive value of C-reactive protein on 30-day and 1year mortality in acute coronary syndromes: an analysis from the ACUITY trial. J Thromb Thrombolysis 2011; 31:154-64.

[15]. Trkulja V, Car S. On-admission serum uric acid predicts outcomes after acute myocardial infarction: systematic review and metaanalysis of prognostic studies. CroatMedJ 2012; 53: 162-72.

[16]. Irving Kushner et a! study of c reactive kinetics after acute myovardial infarction. The journal of clinical investigation volume 61 February 1978 235-342.

[17]. Caixeta A, Stone GW, Mehran R, Lee EA, McLaurin BT, Cox DA, et al. Predictive value of C-reactive protein on 30-day and 1year mortality in acute coronary syndromes: an analysis from the ACUITY trial. J Thromb Thrombolysis 2011; 31:154-64. 